\title{
PENDAMPINGAN PASANGAN RAMAH ANAK (PARANA) DALAM RANGKA PEMBENTUKAN GENERASI EMAS NTB (GEN) DI PROVINSI NTB
}

\section{Assistance Of Child-Friendly Couples (Parana) Program In The Framework Of The Establishment Of NTB Golden Generation (Gen) In NTB Province}

\author{
Rosiady Husaenie Sayuti ${ }^{* 1}$, Khaerul Anwar ${ }^{2}$, Siti Aisyah Hidayati ${ }^{3}$ \\ ${ }^{1}$ Program Studi Sosiologi Universitas Mataram, ${ }^{2}$ Widyaiswara Bapelkes Provinsi NTB, ${ }^{3}$ Fakultas \\ Ekonomi dan Bisnis Universitas Mataram
}

Jl. Majapahit Nomor 62 Kota Mataram, Provinsi NTB

Alamat korespondensi: sayuti@unram.ac.id

(Tanggal Submission: 3 Juni 2021, Tanggal Accepted : 19 Agustus 2021)

\section{Kata kunci :}

GEN, Generasi

Emas NTB,

Parana, Stunting, NTB

\begin{abstract}
Abstrak :
Kualitas sumber daya manusia di provinsi NTB masih tertinggal dibandingkan beberapa provinsi lain. Riset Kesehatan Dasar (Riskesdas) menunjukkan angka stunting (pendek) di provinsi NTB sebesar 48,3\% (2010) dan merupakan tertinggi kedua di Indonesia. Tahun 2018 prevalensi stunting di NTB menurun menjadi $33,49 \%$, dan tetap menjadi masalah kesehatan masyarakat. Tujuan kegiatan pengabdian kepada masyarakat ini adalah untuk mendukung percepatan penanggulangan stunting di provinsi Nusa Tenggara Barat melalui program Generasi Emas NTB (GEN). Program Generasi Emas NTB menggunakan pendekatan pemberdayaan keluarga, melalui pembentukan keluarga atau Pasangan Ramah Anak (PARANA). Pembentukan PARANA melalui serangkaian tahapan mulai Pra Intervensi, intervensi dan evaluasi. Dalam implementasinya, pembentukan PARANA dilakukan dengan metode "pendampingan keluarga" atau mentoring oleh Kader dan Bidan desa yang terlatih. Proses pendampingan dilakukan dengan kunjungan rumah dan melalui kelompok belajar atau kelas ibu. Pendampingan PARANA bertujuan untuk meningkatkan pemahaman dan keterampilan sasaran dalam pengasuhan anak sehingga anak tumbuh dan berkembang dengan baik. Pada akhir periode 1000 Hari Pertama Kehidupan, dilakukan penilaian terhadap pasangan, dan yang memenuhi syarat "ramah anak" diberikan Sertifikat PARANA. Kegiatan pendampingan PARANA telah dilaksanakan di 100 Desa/ Kelurahan se-NTB tahun 2017-2018, dengan sasaran sebanyak 8.366 pasangan. Pada akhir 2020 dilaksanakan sertifikasi PARANA di seluruh Kabupaten/Kota se-NTB. Dari 2.456 pasangan yang disertifikasi, sebanyak 1.705 pasangan atau 69,42\% termasuk kategori "Ramah Anak".
\end{abstract}

Panduan sitasi / Citation guidance (APPA $7^{\text {th }}$ edition) :

Sayuti, R. H., Anwar, K., Hidayati, A. A. (2021). Pendampingan Pasangan Ramah Anak (Parana) Dalam Rangka Pembentukan Generasi Emas Ntb (Gen) Di Provinsi Ntb. Abdi Insani, 8 (2), 205-215. http://doi.org/10.29303/abdiinsani.v8i2.402 


\section{PENDAHULUAN}

Kualitas sumber daya manusia di provinsi NTB masih tertinggal dibandingkan beberapa provinsi lain. Salah satu tolok ukurnya adalah prevalensi stunting atau pendek pada balita. Stunting adalah kondisi gagal tumbuh pada anak balita akibat kekurangan gizi kronis terutama pada 1.000 Hari Pertama Kehidupan (HPK). Stunting mempengaruhi pertumbuhan dan perkembangan otak. Anak stunting juga memiliki risiko lebih tinggi menderita penyakit kronis di masa dewasanya. Bahkan, stunting dan malnutrisi diperkirakan berkontribusi pada berkurangnya 2-3\% Produk Domestik Bruto (PDB) setiap tahunnya (Bappenas, 2007; Setneg $\mathrm{RI}, 2013)$.

Secara nasional, prevalensi stunting selama 10 tahun terakhir menunjukkan tidak adanya perubahan yang signifikan dan ini menunjukkan bahwa masalah stunting perlu ditangani segera. Hasil Riset Kesehatan Dasar (Riskesdas) 2018 menunjukkan 30,8\% atau sekitar 7 juta balita menderita stunting di seluruh Indonesia. Masalah gizi lain terkait dengan stunting yang masih menjadi masalah kesehatan masyarakat adalah anemia pada ibu hamil $(48,9 \%)$, Berat Bayi Lahir Rendah atau BBLR $(6,2 \%)$, balita kurus atau wasting $(10,2 \%)$ dan anemia pada balita (Kemenkes RI, 2018).

Data Riset Kesehatan Dasar (Riskesdas) menunjukkan angka stunting (pendek) di provinsi NTB mengalami penurunan dari 48,3\% (2010) menjadi 45,3\% (2013) dan menurun lagi menjadi 33,49 \% pada tahun 2018. Meskipun demikian, angka stunting NTB masih diatas angka stunting nasional sebesar 27,6 \% (2019) dan termasuk 10 provinsi dengan angka stunting tertinggi, bersama proviunsi NTT, Sulawesi Barat, Gorontalo, Aceh, Kalimantan Tengah, Kalimantan Selatan, Kalimantan Barat, Sulawesi Tenggara, dan Sulawesi Tengah. Stunting tidak bisa terlepas dari penanganan anak Wasting (gizi kurang dan gizi buruk), yang berisiko 3 kali menderita stunting jika tidak ditangani dengan baik. Angka wasting provinsi NTB tahun 2018 sebesar 14,4 \% atau lebih tinggi dari angka wasting nasional sebesar 7,44 \% (Bappeda NTB, 2020a).

Penurunan stunting memerlukan intervensi yang terintegrasi, mencakup intervensi gizi spesifik dan gizi sensitif. Sejalan dengan inisiatif Percepatan Penurunan Stunting, pemerintah meluncurkan Gerakan Nasional Percepatan Perbaikan Gizi (Gernas PPG) yang ditetapkan melalui Peraturan Presiden Nomor 42 tahun 2013 tentang Gernas PPG dalam kerangka 1.000 HPK (Setneg RI, 2013).

Mengacu pada "The Conceptual Framework of the Determinants of Child Undernutrition", "The Underlying Drivers of Malnutrition", dan "Faktor Penyebab Masalah Gizi Konteks Indonesia" penyebab langsung masalah gizi pada anak termasuk stunting adalah rendahnya asupan gizi dan status Kesehatan (Nasrun \& Rahmania, 2018). Penurunan stunting menitikberatkan pada penanganan penyebab masalah gizi, yaitu faktor yang berhubungan dengan ketahanan pangan khususnya akses terhadap pangan bergizi (makanan), lingkungan sosial yang terkait dengan praktik pemberian makanan bayi dan pengasuhan anak, akses terhadap pelayanan kesehatan untuk pencegahan dan pengobatan (kesehatan), serta kesehatan lingkungan yang meliputi tersedianya sarana air bersih dan sanitasi (lingkungan). Keempat faktor tersebut mempengaruhi asupan gizi dan status kesehatan ibu dan anak. 
Intervensi terhadap keempat faktor tersebut diharapkan dapat mencegah masalah gizi, baik kekurangan maupun kelebihan gizi (Endang et al., 2012).

Sesuai amanat RPJPD Provinsi NTB 2005-2025 pada misi ke-2 yaitu "Mewujudkan Masyarakat Sejahtera" serta misi ke-3 RPJMD Provinsi NTB 2019-2023 yaitu "Akselerasi Peningkatan Daya Saing Sumber Daya Manusia Sebagai Pondasi Daya Saing Daerah", maka masalah stunting telah menjadi prioritas daerah untuk ditanggulangi. Upaya penanggulangan stunting dilakukan melalui integrasi dan sinkronisasi program/kegiatan, terfokus dan berkesinambungan (Bappeda NTB, 2020b). Karena itu telah dirumuskan dan ditetapkan sejumlah program unggulan dan program inovatif sebagai kebijakan daerah yang mendukung percepatan penanggulangan stuting di NTB, salah satunya adalah program Generasi Emas NTB atau GEN.

Secara operasional, perwujudan Generasi Emas NTB itu ditempuh melalui pendekatan pemberdayaan keluarga, sehingga terbentuk keluarga yang memiliki pola asuh yang baik terhadap anak-anaknya, yang kemudian keluarga atau pasangan ini disebut sebagai "Pasangan Ramah Anak" atau PARANA. PARANA adalah pasangan atau keluarga yang menerapkan pola asuh yang baik kepada anaknya pada periode $1000 \mathrm{HPK}$, yaitu sejak masa kehamilan sampai anak berusia 2 tahun. Pola asuh yang diberikan juga merupakan proses pemberian "hak tumbuh kembang" kepada anak.

Implementasi pembentukan PARANA di lapangan adalah dengan "pendampingan keluarga" atau mentoring. Pendampingan ini merupakan proses komunikasi, informasi dan edukasi (KIE) dengan cara kunjungan rumah dan melalui kelompok belajar atau kelas ibu, yang dilakukan oleh Bidan desa dan kader terlatih. Pendampingan PARANA bertujuan untuk mengedukasi pasangan agar memiliki pola asuh yang baik terhadap anaknya sehingga anak tumbuh dan berkembang dengan baik. Pola asuh yang baik, khususnya pola asuh gizi, dapat meningkatkan status gizi anak dalam keluarga tersebut (Endang et. al.,2012). Secara umum kegiatan pendampingan ini berkontribusi terhadap percepatan penanggulangan stunting di provinsi Nusa Tenggara Barat. Pada akhir periode 1000 Hari Pertama Kehidupan, dilakukan penilaian hasil dampingan yang disebut sertifikasi PARANA. Keluarga atau pasangan yang telah memenuhi syarat "ramah anak"-dengan system scoring-akan diberikan sertifikat PARANA.

Kegiatan pendampingan PARANA telah dilaksanakan di 100 Desa/ Kelurahan se-NTB tahun 2017-2018, dengan sasaran sebanyak 8.366 pasangan. Genap 1000 hari implementasi (periode 1000 HPK), pada tahun 2019 dan 2020 dilakukan penilaian atau sertifikasi PARANA di 100 Desa/Kelurahan tersebut. Hasil sertifikasi PARANA merupakan persentase pasangan atau keluarga yang telah berhasil memberikan pengasuhan yang baik sehingga anaknya akan tumbuh dan berkembang menjadi anak yang unggul, sehat, cerdas dan berprestasi di masa depan. Tujuan kegiatan pengabdian kepada masyarakat ini adalah untuk mendukung percepatan penanggulangan stunting di provinsi Nusa Tenggara Barat melalui program Generasi Emas NTB (GEN). 


\section{METODE KEGIATAN}

Kegiatan atau intervensi pembinaan Pasangan Ramah Anak atau PARANA ini dilakukan sejak tahun 2017 dan 2018, berlokasi di 100 desa/kelurahan se-NTB atau 10 Desa/ Kelurahan per Kabupaten/Kota. Kegiatan Pembinaan PARANA ini dilakukan dengan tahapan sebagai berikut :

\section{PRA INTERVENSI}

\subsection{Penyusunan konsep kegiatan}

Kegiatan ini bertujuan untuk menyusun konsep atau substansi kegiatan. Kegiatan dilakukan dalam bentuk survey atau formative study di 40 Desa di Lombok Tengah dan Lombok Timur, pada tahun 2015. Hasil formative study telah dibahas dalam suatu workshop. Hasil workshop kemudian di-implementasikan di 10 desa, yaitu di Lombok Tengah (4 Desa) dan Lombok Timur (6 Desa), pada tahun 2016, untuk menguji konsep atau pendekatan program. Secara umum ada 3 pendekatan yang diterapkan, yaitu : perbaikan pola asuh anak dalam keluarga (PARANA), penguatan institusi pelayanan dasar yaitu keterpaduan Posyandu, PAUD dan BKB (PAUD HI), dan social bussines melalui pembentukan Lembaga ekonomi mikro (koperasi) di tingkat desa. Kegiatan-kegiatan yang direncanakan adalah : penyusunan kurikulum PARANA, penyusunan kurikulum PAUD Non Formal, Pelatihan Kader dan Bidan PARANA, pengadaan MMN, Pembentukan Koperasi di desa dan sertifikasi PARANA.

1.2 Penentuan lokasi Desa dan kelurahan yang menjadi lokus pembinaan (intervensi).

Desa dan kelurahan yang menjadi lokus intervensi merupakan desa yang memiliki prevalensi gizi buruk, stunting yang tinggi dan adanya kematian ibu dan bayi dalam 1 tahun, di setiap Kabupaten/Kota. Dengan kriteria tersebut dan dengan mempertimbangkan sumber daya (APBD Provinsi) terpilih $100 \mathrm{Desa} /$ Kelurahan seNTB atau 10 Desa/Kelurahan per kabupaten/kota. Daftar Desa/ kelurahan ini ditetapkan dengan SK Gubernur. Daftar Desa / kelurahan terlampir. Kegiatan ini dilakukan tahun 2016.

\subsection{Penentuan kegiatan}

Memperhatikan hasil uji coba program di 10 Desa di Lombok Tengah dan Lombok Timur pada tahun 2016, maka untuk implementasi di 100 Desa/kelurahan, dipilih 2 kegiatan, yaitu : pembinaan PARANA dan pemberian Multi Mikro Nutrien (MMN) bagi semua ibu hamil di lokus kegiatan.

\subsection{Penentuan Sasaran}

Sasaran kegiatan pembinaan PARANA adalah ibu dan anak pada periode 1000

HPK, dan diawali dengan sasaran ibu hamil, yang kemudian diikuti sampai anak berusia 2 tahun. Kegiatan diawali dengan pendataan sasaran di setiap desa. Kegiatan 
dilakukan oleh Bidan Desa setempat dengan sumber data dari Kohor Ibu atau daftar ibu hamil saat itu. Kegiatan ini dilakukan pada thun 2017.

\section{INTERVENSI}

\subsection{Pelatihan PARANA}

Kegiatan ini dilaksanakan secara berjenjang pada tahun 2017, dengan tujuan untuk meningkatkan pemahaman dan keterampilan Bidan GEN, Kader GEN serta Guru PAUD mengenai pelaksanaan pembinaan PARANA. Pelatihan difasilitasi oleh SID. Pelatihan menggunakan modul PARANA/ KARANA yang dikembangkan SID, yang secara umum berisi keterampilan dalam pengasuhan anak (parenting).

\subsection{Pendampingan PARANA}

Kegiatan ini bertujuan untuk mengedukasi atau meningkatkan pemahaman ibu hamil dalam pengasuhan anak sejak dalam kandungan sampai anak berusia 2 tahun. Kegiatan ini merupakan proses KIE (konseling individual), dimana ibu hamil diharapkan didampingi oleh suami atau pasangan. Pendampingan ini juga terpadu dengan kegiatan ANC (pelayanan periksa hamil) yang dilakukan oleh Bidan Desa setempat. Kegiatan pendampingan PARANA dilakukan oleh Bidan GEN (1 orang per desa) dan Kader GEN (3 orang per desa) yang telah dilatih PARANA. Pendampingan dilakukan dengan kunjungan rumah ke rumah sasaran oleh kader GEN didampingi bidan GEN. Kegiatan dilakukan minimal 1 kali per bulan selama kehamilan. Proses KIE di rumah sasaran menggunakan alat bantu/ media lembar balik PARANA. Untuk ibu hamil yang berdekatan rumahnya, dilakukan secara berkelompok.

\subsection{Kelas Ibu PARANA}

Pendampingan PARANA selain dilakukan dengan kunjungan rumah, juga dilakukan melalui kelompok belajar ibu hamil atau kelas ibu PARANA. Kelas Ibu PARANA bertujuan untuk meningkatkan pengetahuan, merubah sikap dan perilaku ibu hamil tentang pola asuh kehamilan, persalinan, bayi baru lahir dan anak bawah dua tahun. Kelas Ibu merupakan kelompok belajar ibu hamil dan ibu baduta (sasaran 1000 HPK) dengan jumlah peserta maksimal 20 orang. Kelas Ibu PARANA merupakan pengembangan dari Kelas Ibu Hamil dengan penambahan materi stimulasi psikososial dan pola asuhan gizi. Referensi dan bahan kelas Ibu PARANA adalah Buku KIA, Lembar balik Kelas Ibu Hamil, Buku "Menjadi Orang Tua Hebat" dan Modul PARANA. Metodenya dengan diskusi, tukar pengalaman antara ibu hamil/ ibu baduta dengan tenaga kesehatan dan Praktek (jika diperlukan). Kegiatan. Kelas Ibu PARANA dilaksanakan dalam 1 sampai 4 kali tatap muka, tergantung ketersediaan anggaran di desa/ kelurahan.

\subsection{Pemberian Multi Mikro Nutrient (MMN)}


Tujuan pemberian MMN adalah untuk meningkatkan asupan gizi ibu hamil, teruatama zat gizi mikro yang berpengaruh terhadap status anemia ibu hamil. Sasaran pemberian MMN adalah ibu hamil yang mengikuti pembinaan PARANA. Jumlah MMN yang diberikan selama hamil adalah 100 tablet, atau untuk 100 hari ( 3 bulan lebih). Intervensi zat gizi mikro ini adalah bagian dari pelayanan ANC. Jika ibu hamil telah menerima MMN, maka tidak diberikan Tablet Tambah Darah (TTD).

\section{EVALUASI}

Evaluasi dilakukan melalui kegiatan sertifikasi PARANA, pada sasaran (anak) yang sudah mencapai usia 2 tahun atau akhir dari periode 1000 HPK. Sertifikasi PARANA adalah proses pemberian pengakuan kepada pasangan / keluarga yg telah memberikan hak tumbuh kembang kepada anaknya. Tujuannya adalah untuk melihat sejauh mana anak-anak mendapatkan pengasuhan yang baik sejak dalam kandungan sampai anak berusia 2 tahun. Kegiatan ini juga ingin mengukur sejauh mana hak tumbuh kembang anak diberikan secara optimal. Di lain sisi, kegiatan sertifikasi ini juga dapat digunakan untuk melihat seberapa efektif program / intervensi pemerintah dirasakan maanfaatnya oleh seorang anak, khususnya anak dalam periode 1000 HPK.

Sertifikasi berbasis individu (pasangan). Indikator yang dinilai adalah indicator pada pasangan, misalnya Pendidikan istri dan suami. Ada 33 indikator yang dinilai dari pasangan tersebut, yaitu indicator-indikator yang berhubungan dengan tumbuh kembang anak, sejak dalam kandungan sampai anak 2 tahun. (Daftar indikator terlampir). Dengan skoring dan pembobotan terhadap indicator, dapat ditentukan pasangan yang memenuhi kriteria "ramah" terhadap anak.

\section{HASIL DAN PEMBAHASAN}

Kegiatan pembinaan PARANA pada tahun 2017 dan 2018 mencakup sasaran sebanyak 8.366 pasangan di 100 desa/kelurahan lokasi GEN, atau rata-rata ada 83 orang sasaran per desa/kelurahan. Sasaran telah mendapatkan pendampingan oleh Kader maupun Bidan GEN yang sudah dilatih. Kader GEN yang berjumlah 3 orang (per desa) membagi diri untuk melakukan kunjungan rumah ke pasangan-pasangan tersebut. Dengan jumlah sasaran yang cukup besar di setiap desa (83 pasangan) maka seorang kader mendapat bagian membina sekitar 28 orang per bulan. Beban pendampingan sebanyak ini bagi seorang kader cukup berat, terutama untuk desa/kelurahan di Pulau Lombok yang jumlah sasaran per desanya lebih besar dari sasaran di Pulau Sumbawa. Sebagai contoh, Desa Pringgabaya, Lombok Timur, jumlah sasaran sebanyak 236 pasangan, dan dibandingkan dengan salah satu desa di Bima, jumlah sasarannya 34 pasangan. Untuk mengatasi beban kerja yang cukup berat, kader biasanya membina sasaran sekali dalam 2 atau 3 bulan. Alternatif lain adalah dengan memperbanyak kader. Bidan yang sudah terlatih, akan memberikan pelatihan singkat (brifing) kepada kader-kader tambahan tersebut. 


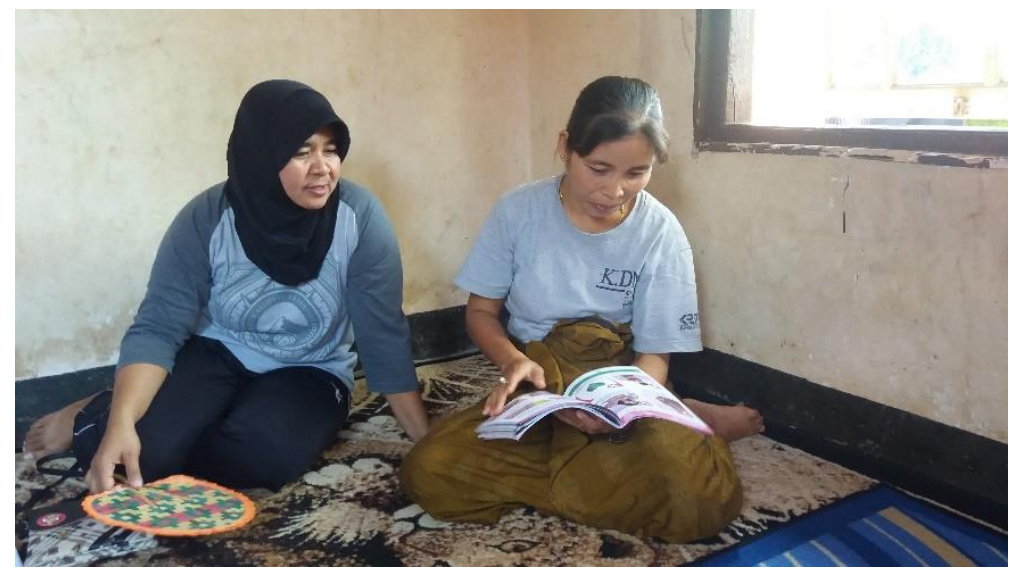

Gambar 1. Pendampingan PARANA di rumah sasaran di Lombok Timur

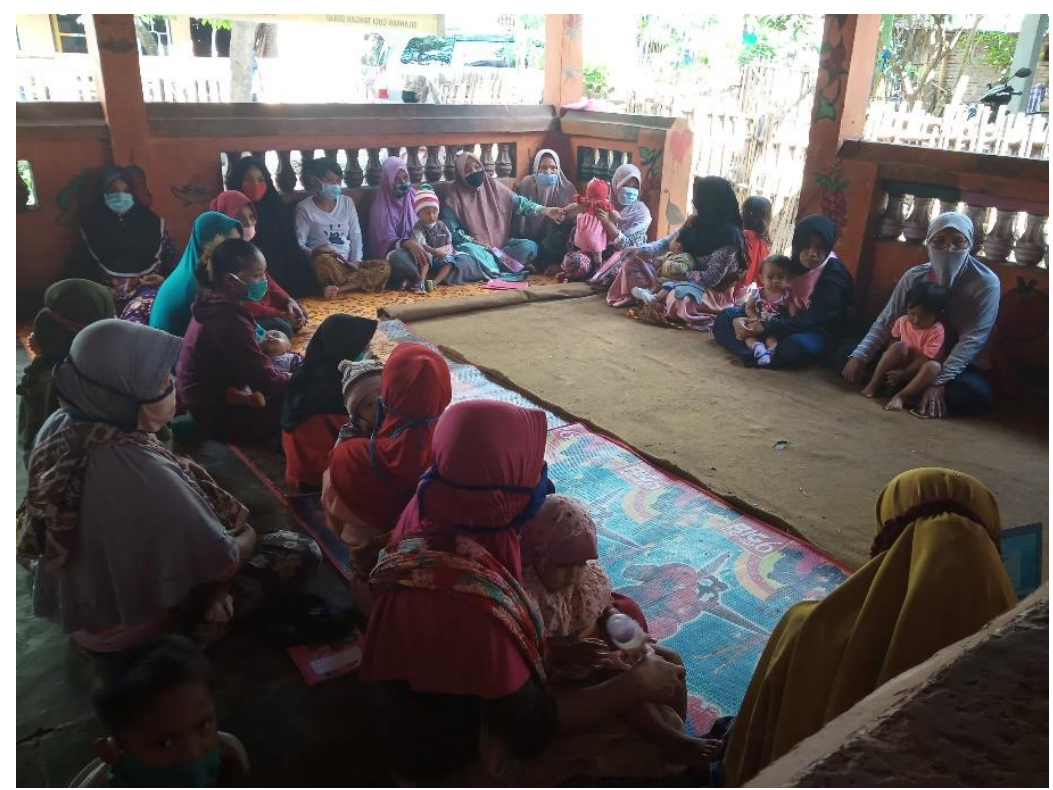

Gambar 2. Kelas Ibu PARANA di Lombok Tengah

Berdasarkan sertifikasi PARANA yang dilakukan pada tahun 2019 dan 2020, oleh Koordinator GEN Kab/Kota dan Bidan Desa, terdata 2.456 pasangan (pada akhir 2020). Sertifikasi menggunakan instrument / format (terlampir). Sertifikasi dilakukan dengan kunjungan ke rumah sasaran, kemudian dilakukan wawancara dan observasi lingkungan tempat tinggal. Data kemudian diolah dan dianalisa di Sekretariat GEN Provinsi NTB. Dari 2.456 pasangan tersebut, sebanyak 1.705 pasangan atau 69,42 \% termasuk kategori "Ramah Anak". Pasangan dengan kategori ramah anak ini adalah pasangan yang telah memenuhi minimal $90 \%$ indikator-indikator PARANA. Cakupan PARANA per Kabupaten/Kota sebagai berikut : 


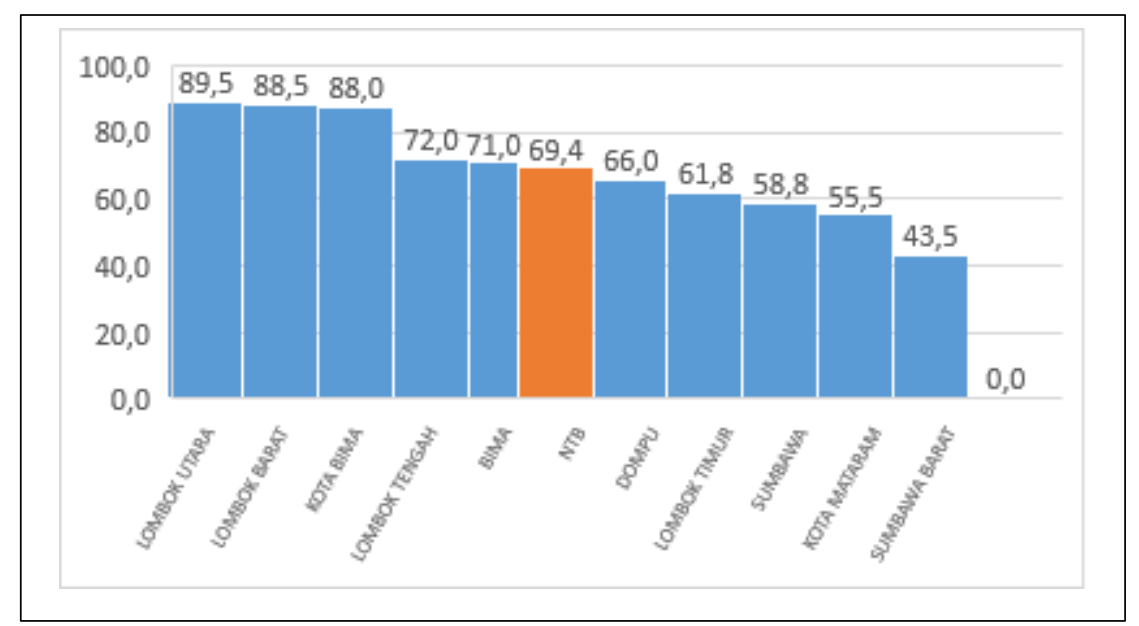

Gambar 3. Distribusi Cakupan PARANA berdasarkan Kabupaten/Kota 2019-2020

Grafik di atas adalah gambaran distribusi cakupan PARANA di setiap Kabupaten/Kota se-NTB. Kabupaten Lombok Utara, Kabupaten Lombok Barat dan Kota Bima memiliki cakupan tertinggi, yaitu diatas $80 \%$. Sementara itu Kabupaten Sumbawa Barat memiliki cakupan PARANA terkecil yaitu 43,5\%. Data sasaran yang disertifikasi sebanyak 2.456 pasangan atau sekitar 30 \% dari total sasaran. Kegiatan sertifikasi PARANA masih akan dilaksanakan untuk sisa sasaran yang belum tersertifikasi.

Berikut ini adalah capaian indicator PARANA untuk semua sasaran (agregat).

\begin{tabular}{|c|c|c|c|}
\hline No & $\begin{array}{l}\text { Tahap Tumbuh } \\
\text { Kembang }\end{array}$ & Indikator & Cakupan (\%) \\
\hline \multirow[t]{2}{*}{1} & \multirow{2}{*}{$\begin{array}{l}\text { Usia ideal untuk } \\
\text { tumbuh kembang } \\
\text { anak yang baik. }\end{array}$} & 1. Suami dengan usia ideal & 91,3 \\
\hline & & 2. Istri dengan usia ideal & 94,7 \\
\hline \multirow[b]{2}{*}{2} & \multirow{2}{*}{$\begin{array}{l}\text { Tingkat Pendidikan } \\
\text { yang ideal untuk } \\
\text { tumbuh kembang } \\
\text { anak yang baik. }\end{array}$} & 3. Suami dengan tingkat Pendidikan ideal & 60,3 \\
\hline & & 4. Istri dengan tingkat Pendidikan ideal & 54,6 \\
\hline \multirow[t]{8}{*}{3} & \multirow{8}{*}{$\begin{array}{l}\text { Riwayat kehamilan } \\
\text { ibu }\end{array}$} & 5. Kehamilan pertama dan kedua & 73,3 \\
\hline & & $\begin{array}{l}\text { 6. Periksa hamil minimal } 4 \text { kali selama } \\
\text { kehamilan terakhir }\end{array}$ & 83,4 \\
\hline & & 7. Periksa kehamilan di tenaga kesehatan & 100,0 \\
\hline & & 8. Periksa di fasilitas kesehatan & 99,9 \\
\hline & & 9. Mengalami tanda bahaya kehamilan & 2,6 \\
\hline & & 10. Imunisasi TT lengkap & 93,2 \\
\hline & & 11. Aktifitas fisik / senam kehamilan & 97,4 \\
\hline & & 12. Suami ibu hamil perokok aktif & 79,6 \\
\hline 4 & Riwayat persalinan & $\begin{array}{l}\text { 13. Persalinan terakhir dibantu tenaga } \\
\text { kesehatan }\end{array}$ & 99,3 \\
\hline
\end{tabular}




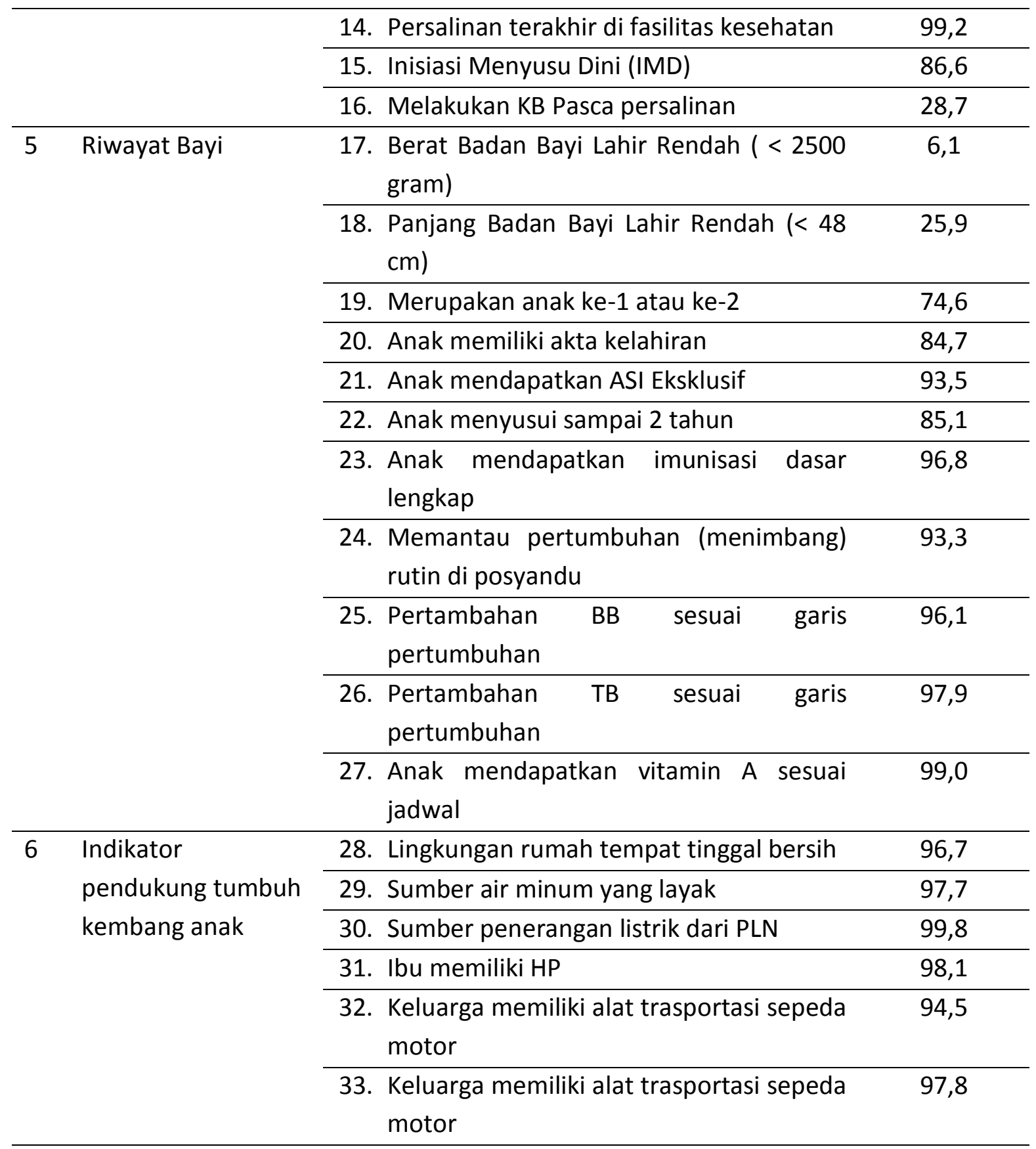

Terdapat 33 indikator yang berhubungan, berpengaruh, berinteraksi dengan tumbuh kembang anak. Pencapaian ke-33 indikator secara optimal (minimal $90 \%$ ) akan menentukan kualitas tumbuh kembang anak. Dalam analisis data PARANA, penentuan kategori "ramah anak" didasarkan pada pencapaian pasangan itu terhadap ke-33 indikator. Sementara data di atas adalah data agregat dari 2.456 pasangan yang di-sertifikasi.

Dari 33 indikator di atas, ada beberapa indicator yang perlu mendapat perhatian dalam rangka perbaikan tumbuh kembang anak, yaitu :

1. Sekitar $40-45 \%$ pasangan suami istri berpendidikan tertinggi adalah SLTP.

2. Sebanyak $26,7 \%$ pasangan suami istri memiliki lebih dari 2 anak. 
3. Sebanyak $79,6 \%$ suami dari ibu hamil adalah perokok aktif, yang memungkinkan ibu hamil dan anaknya terpapar asap rokok.

4. Sekitar $13 \%$ ibu bersalin tidak memberikan IMD kepada bayinya.

5. Sekitar $71 \%$ ibu bersalin belum ber-KB sesaat setelah melahirkan.

6. Sebanyak $25,9 \%$ bayi lahir dengan Panjang Badan kurang dari $48 \mathrm{~cm}$, yang merupakan indikasi awal terhambatnya pertumbuhan anak (stunting).

7. Sekitar $15 \%$ anak belum memiliki akta kelahiran

Dari gambaran pencapaian 33 indikator di atas, sebanyak 7 indikator yang memerlukan perhatian dan 26 indikator lainnya sudah terpenuhi. Hal ini menunjukkan bahwa program tumbuh kembang anak (kesehatan, Pendidikan dan pemberdayaan anak serta perempuan) sudah cukup memadai atau sudah terakses dengan baik oleh pasangan atau keluarga.

Terhadap 7 indikator yang perlu mendapat perhatian maka ada beberapa rekomendasi yang diberikan :

1. Perlunya upaya peningkatan Pendidikan pasangan suami istri

2. Perlunya diaktifkan promosi KB untuk pengaturan jarak kehamilan dan KB pasca salin.

3. Perlunya digencarkan promosi pola asuh gizi yang baik kepada ibu hamil, untuk menekan angka gangguan pertumbuhan bayi (Panjang bayi lahir rendah), pemberian IMD.

4. Perlunya diintensifkan ANC yang berkualitas, termasuk konseling tentang bahaya asap rokok dan pentingnya kepemilikan akta kelahiran.

\section{KESIMPULAN DAN SARAN}

1. Kegiatan Generasi Emas NTB telah dilaksanakan sebagai langkah percepatan penanggulangan stunting di Nusa Tenggara Barat.

2. Pendampingan Pasangan Ramah Anak (PARANA) telah dilaksanakan terhadap 8.366 pasangan di 100 Desa/Kelurahan se-NTB tahun 2017-2018.

3. Hasil sertifikasi PARANA pada tahun 2019-2020 terhadap 2.456 pasangan menemukan bahwa 69,45 \% pasangan termasuk kategori Pasangan Ramah Anak (PARANA). Hal ini juga berarti bahwa sebanyak $69,45 \%$ pasangan yang dibina telah memberikan pola asuh yang baik terhadap anaknya.

4. Ada 7 variabel yang berkontribusi terhadap tumbuh kembang anak termasuk untuk pencegahan stunting yang perlu mendapat perhatian yaitu: tingkat pendidikan suamiistri, jumlah kehamilan (anak) lebih dari 2 kali, angka suami perokok aktif, pemberian IMD kepada bayi, KB Pasca Salin, Panjang Bayi Lahir yang kurang dari $48 \mathrm{~cm}$, dan kepemilikan akta kelahiran.

5. Saran yang perlu disampaikan yang perlu dilakukan untuk mengoptimalkan cakupan 7 variabel di atas adalah : 1) perlunya upaya peningkatan pendidikan pasangan suami istri, 2) perlunya diaktifkan promosi KB untuk pengaturan jarak kehamilan dan KB pasca salin, 3) perlunya digencarkan promosi pola asuh gizi yang baik kepada ibu hamil, untuk 
menekan angka gangguan pertumbuhan bayi (panjang bayi lahir rendah), pemberian IMD, dan 4) perlunya diintensifkan ANC yang berkualitas, termasuk konseling tentang bahaya asap rokok dan pentingnya kepemilikan akta kelahiran.

\section{DAFTAR PUSTAKA}

Bappeda NTB. (2020a). Peraturan Gubernur NTB Nomor 68 Tahun 2020 Tentang Aksi Pencegahan Penurunan Stunting Trintegrasi. Mataram : Bappeda Provinsi NTB.

Bappeda NTB. (2020b). Rencana Pembangunan Jangka Menengah Provinsi NTB 2019-2024. Mataram : Bappeda Provinsi NTB.

Bappenas. (2007). Rencana Aksi Nasional Pangan dan Gizi 2006-2010. Jakarta : Bappenas RI.

Endang, L. A., Kusharisupeni, Atmarita, \& Untoro, R. (2012). Status Gizi Ibu Hamil dan Penyakit Tidak Menular pada Dewasa. Jurnal Kesehatan Masyarakat Nasional, 7(4).

Kemenkes RI. (2018). Laporan Riskesdas 2018. Jakarta : Kemenkes RI.

Nasrun, M. A., \& Rahmania. (2018). Hubungan Indikator Keberhasilan Pembangunan Ekonomi Dengan Stunting Di Indonesia. Prosiding SATIESP.

Setneg RI. (2013). Peraturan Presiden Nomor 42 tahun 2013 tentang Gernas Percepatan Perbaikan Gizi. Jakarta : Setneg RI. 